\title{
Fragmenter
}

\section{FRIEDRICH SCHLEGEL}

\section{Lyceum der schönen Kunste (1797)}

[42] Filosofien er ironiens egentlige hjemsted, som man helst ville definere som logisk skønhed: thi overalt, hvor der i mundtlige eller skrevne samtaler, og ikke kun helt systematisk, filosoferes, bør man yde og kræve ironi; og sågar Stoikerne anså urbaniteten for at være en dyd. Ganske vist findes der også en retorisk ironi, som anvendt sparsomt, giver en fortræffelig virkning, især udi det polemiske; dog er den mod den sokratiske ironi, hvad den mest fremragende kunsttales pragt er mod en gammel tragedie i høj stil. Alene poesien kan fra denne side også hæve sig op til filosofiens højde, og dens grundlag er ikke ironiske steder, som retorikkens. Der findes gamle og moderne digte, som gennemgående i det hele og overalt ånder ironiens guddommelige åndeslør. Der lever i disse et virkeligt transcendentalt buffoneri. I det indre, stemningen, som overser alt, og som hæver sig uendeligt over alt betinget, også over egen kunst, dyd eller genialitet: i det ydre, i udførelsen en almindelig, god italiensk buffos mimiske manér.

Ideen $(\mathbf{1 8 0 0})^{1}$

[156]

Til Novalis

Ikke på grænsen svæver du, men i din ånd har poesi og filosofi dybt og kærligt trængt sig igennem. Din ånd stod mig nærmest ved disse billeder af den ubegrebne sandhed. Hvad du har tænkt, tænker jeg, hvad jeg har tænkt, vil du tænke, eller har allerede 
tænkt. Der findes misforståelser, som blot bekræfter den højeste indforståethed. Læren om den evige Orient tilhører alle kunstnere. Dig nævner jeg i stedet for alle andre.

\section{Athenæum (1800)}

[116] Den romantiske poesi er en progressiv universalpoesi. Dens bestemmelse er ikke blot at genforene alle poesiens adskilte genrer og bringe poesien i berøring med filosofien og retorikken. Den både vil og skal også snart blande, snart sammensmelte poesi og prosa, genialitet og kritik, kunstpoesi og naturpoesi; den skal gøre poesien til et levende fællesskab og livet og samfundet poetisk, den skal poetisere vitsen og tilføre og mætte kunstformerne med solidt dannelsesstof af enhver art og besjæle ved humorens svingnịinger. Den omfatter alt, når det blot er poetisk, fra det største kunstsystem, som igen indeholder flere systemer i sig, til sukket og kysset, som det digtende barn henånder i kunstløs sang. Den kan fortabe sig sådan i det fremstillede, at man skulle tro, at det var dens eet og alt at karakterisere poetiske individer af enhver art; og dog findes der endnu ikke en form, der ville være gjort sådan, at den fuldstændigt udtrykte forfatterens ånd, således at mange kunstnere, der også kun ville skrive en roman, helt tilfældigt har fremstillet sig selv. Kun den kan ligesom eposet blive et spejl af hele den omgivende verden, et billede på tidsalderen. Og dog kan også den, fri af alle reale og ideale interesser, for det meste svæve på den poetiske refleksions vinger i midten mellem det fremstillede og den fremstillende, den kan igen og igen potensere denne refleksion og mangfoldiggøre den som i en endeløs række af spejle. Den er i stand til den højeste og mest alsidige dannelse; ikke blot indefra og ud, men også udefra og ind; idet den organiserer alle dele i det, der skal være et hele i dens frembringelser, hvorved der åbner sig udsigt til en grænseløst voksende klassicitet. Den romantiske poesi er blandt kunstarterne, hvad vitsen er for filosofien, og hvad selskab, omgang, venskab og kærlighed er for livet. Andre digteriske former er udtømt og kan nu analyseres fuldstændigt. Den romantiske 
digtart er endnu under tilblivelse; ja det er dens egentlige væsen, at den er evigt vordende og aldrig kan fuldendes. Den kan ikke udtømmes ved en teori, og kun en divinatorisk kritik turde vove at karakterisere dens ideal. Den alene er uendelig, ligesom den alene er fri og anerkender det som sin forste lov, at digterens vilkår ikke tåler nogen lov over sig. Den romantiske digtart er den eneste, som er mere end en art, og samtidig digtekunsten selv: thi $i$ en vis forstand er al poesi romantisk eller bør være det.

\section{Om uforståelighed $(1800)^{2}$}

Nogle af den menneskelige eftertankes genstande pirrer os fordi det ligger i dem eller i os - til dybere og dybere eftertanke, og jo mere vi følger denne pirring og fortaber os i dem, jo mere bliver de alle til een genstand, som vi, alt efter om det er i os eller uden for os vi søger og finder den, karakteriserer som tingenes natur eller som menneskets bestemmelse. Andre genstande ville måske. aldrig kunne fange vor opmærksomhed, hvis vi i hellig ensomhed udelukkende og ensidigt viede vor betragtning denne alle genstandes genstand; hvis vi ikke stod i forbindelse med mennesker, fra hvis gensidige meddelelse først sådanne forhold og forholdsbegreber viser sig, der som eftertankens genstande ved nærmere refleksion formerer og forvikler sig mere og mere, altså også heri følger den modsatte gang.

Af alt det, der forholder sig til idéernes meddelelse, hvad kan vel være mere tiltrækkende end spørgsmålet om, hvorvidt den overhovedet er mulig; og hvor ville man have bedre lejlighed til at opstille mange forskellige forsøg omkring muligheden eller umuligheden af denne sag, end hvis man enten selv skriver en journal som Athenæum eller som læser dog tager del i det samme.

Den sunde menneskeforstand, der så gerne vil orientere sig ved etymologiernes ledetråde, når de er nærliggende, kunne let komme frem til den formodning, at det uforståeliges grund skulle ligge i uforstanden. Nu er det særegent for mig, at jeg slet ikke kan lide uforstanden, ejheller de uforstandiges uforstand; men endnu mindre de forstandiges uforstand. Derfor havde jeg 
allerede for længe siden truffet beslutning om at indlede en samtale med læseren om denne materie, og for hans egne øjne, op i hans åbne ansigt at konstruere en anden ny læser efter min opfattelse, ja, hvis jeg skulle finde det nødvendigt, sågar at deducere denne. Jeg mente det ærligt nok, og ikke uden den gamle hang til mysticisme. Jeg ville én gang tage det ret nøjagtigt, ville gennemgå hele min kæde af forsøg, med hensynsløs åbenhed bekende det ofte dårlige resultat, og således efterhånden henlede læseren på en lignende åbenhed og redelighed over for sig selv; jeg ville bevise, at al uforståelighed er relativ, og fremstille hvor uforståelig for mig for eksempel Garve er; 3 jeg ville vise, at ordene ofte forstår sig selv bedre, end dem der bruger dem, ville gøre opmærksom på, at der blandt de filosofiske ord - der ofte står som en skare af for tidligt udsprungne ånder i deres skrifter og forvirrer alt og også udøver verdensåndens usynlige vold mod dem, der ikke vil anerkende dem - må findes hemmelige ordensforbindels er; jeg ville vise, at man netop får den reneste og mest gedigne uforståelighed fra videnskab og kunst, som egentlig går ud på forståen og gøren forståeligt, fra filosofien og filologien; og for at hele opgaven ikke skulle dreje sig om en alt for håndgribelig cirkel, så havde jeg sat mig for denne ene gang i det mindste at være sikkert forståelig. Jeg ville hentyde til det, enhver tids største tænkere (ganske vist kun meget dunkelt) har anet, indtil Kant opdagede kategoriernes tavle, og der blev lys i menneskets ånd; jeg mener et reelt sprog, at vi måtte høre op med at famle med ord, og kunne skue al virkes kraft og sæd. En sådan kabbalas store raseri, hvor der burde læres, hvorledes menneskets ånd forvandler sig selv og derigennem endelig måtte lænke den foranderlige, evigt forvandlede modstander, et sådant mysterium måtte jeg nu ikke fremstille så naivt og nøgent, som jeg i ungdommelig ubetænksomhed i Lucinde havde skildret kærlighedens natur som evig hieroglyf. Jeg måtte således tænke på et populært medium for kemisk at binde den hellige, sarte, flygtige, luftige, duftende og samtidig imponderable tanke. Hvor meget kunne den ellers ikke være blevet misforstået, idet det jo først var gennem den velforståede brug, at alle forståelige misforståelser skulle få en ende? Samtidig havde jeg med inderlig fornøjelse be- 
mærket vor nations progresser; og hvad skal jeg først sige om tidsalderen? Den samme tidsalder, i hvilken vi også for at leve har ægteskabet; tidsalderen, som, for at sige alt med ét ord, fortjener det beskedne, men yderst sigende navn den kritiske tidsalder, sådan at alt nu snart vil blive kritiseret, bortset fra tidsalderen selv, og at alt bliver mere og mere kritisk, og kunstnerne allerede turde nære den retfærdige forhåbning, at menneskeheden endelig ophøjer sig til masse og lærer at læse.

Kun for ganske kort tid siden blev denne tanke om et reelt sprog vakt hos mig igen, og en lysende udsigt åbnede sig for det indre øje. I det nittende århundrede, forsikrer Girtanner os, ${ }^{4} \mathrm{i}$ det nittende århundrede vil man kunne lave guld; og er det ikke endda mere end en formodning, at det nittende århundrede nu snart vil tage sin begyndelse? Med rosværdig sikkerhed og med en interessant ophøjelse siger den værdige mand: „Enhver kemiker, enhver kunstner vil lave guld: køkkenservicet vil være af sølv, af guld." - Hvor gerne vil alle kunstnere nu ikke beslutte sig for stadig at sulte i den sidste, ubetydelige levning af det attende århundrede, og ikke længere opfylde denne store pligt med bedrøvet hjerte; thi de ved, dels at de selv i egen person, dels imidlertid også og desto mere sikkert at deres efterkommere inden længe vil kunne lave guld. At det lige netop er køkkenservicet, der nævnes, har den årsag, at denne skarpsindige ånd netop finder det fortræffeligt skønt og stort ved denne katastrofe, at vi nu ikke mere må bide så mange ryggesløse halvsyrer fra gemene, uædle metaller som bly, kobber, jern o.l. i os. Jeg så sagen fra et andet synspunkt. Jeg havde allerede ofte i det stille beundret guldets objektivitet, ja, jeg kan vel sige tilbedt. Hos kineserne, tænkte jeg, hos englændernë, hos russerne, på øen Japan, hos indbyggerne i Fetz og Marokko, ja, sågar hos kosakker, tscheremisser, baschkirer og mulatter, kort sagt, overalt, hvor der blot findes nogen dannelse og oplysning, er sølvet, guldet begribeligt og gennem guldet alt det øvrige. Om nu enhver kunstner besidder disse materier i tilstrækkelig kvantitet, så må han jo kun skrive sine værker i basrelief, med guldtyper på sølvtavler. Hvem ville tilbagevise en så smukt trykt skrift med den grove ytring, at den var uforståelig? 
Men alt dette er kun hjernespind eller idealer: thi Girtanner er død, og er følgelig nu så langt fra at kunne lave guld, at man tværtimod kun med al kunst ville kunne få så meget jern ud af ham, som ville være nødvendigt for at at forevige hans minde på en lille skuemønt.

Ydermere har klagerne over uforståeligheden så udelukkende været imod Athenæum - det er hændt så ofte og så mangesidigt at deduktionen bedst vil kunne tage sin begyndelse netop der, hvor skoen egentlig trykker os.

En skarpsindig kunstdommer har i Berliner Archiv der Zeit allerede forsvaret Athenæum venligt imod disse bebrejdelser, og dertil valgt det berygtede fragment om de tre tendenser som eksempel. En ovenud heldig tanke! Nøjagtig sådan må man gribe sagen an. Jeg vil slå ind på den samme vej, og for at læseren desto lettere kan indse, at jeg virkelig mener fragmentet er godt, så kan det.stå her nok en gang:

Den franske revolution, Fichtes videnskabslære og Goethes Meister er tidsalderens største tendenser. Den, der tager anstød af denne sammenstilling, den, for hvem ingen revolution kan synes vigtig, med mindre den er højlydt og materiel, han har endnu ikke hævet sig op til det høje, vide standpunkt i menneskehedens historie. Selv i vore tarvelige kulturhistorier - som mest ligner en med fortløbende kommentarer udstyret variantsamling, hvortil den klassiske tekst gik tabt - spiller mangen lille bog, som den larmende mængde i sin tid ikke tog megen notits af, en større rolle end alt, hvad denne bedrev. ${ }^{5}$

Dette fragment skrev jeg i den redeligste hensigt og næsten uden nogen ironi. Den måde, hvorpå det er blevet misforstået, har overrasket mig uudsigeligt, fordi jeg havde forventet misforståelsen fra en helt anden side. At jeg opfatter kunst som menneskehedens kerne, og den franske revolution som en fortræffelig allegori på den transcendentale idealismes system, er rigtignok kun en af mine yderst subjektive anskuelser. Men jeg har jo allerede så ofte og på så forskellige måder givet det til kende, at jeg vel havde lov til at håbe, at læseren endelig havde vænnet sig til det. Alt andet er blot chiffersprog. Den, der ikke kan finde hele Goethes ånd også i Meister, han vil nok søge den forgæves hv- 
orsomhelst. Poesien og idealismen er den tyske kunsts og dannelses centre; det ved da enhver. Men den, der ved det, kan ikke ofte nok blive mindet om, at han ved det. Alle store sandheder af enhver art er helt igennem trivielle, og netop derfor er der ikke noget mere nødvendigt end hele tiden at udtrykke dem påny, og så vidt muligt mere og mere paradoksalt, så det ikke glemmes, at de stadig er der, og at de egentlig aldrig vil kunne udtales helt.

Så langt er alt uden ironi, og må så sandelig ikke misforstås; og alligevel er det hændt i en sådan grad, at en kendt Jakobiner, magister Dyk i Leipzig, endog har villet finde demokratiske tænkemåder deri.

Der er ganske vist i fragmentet noget andet, som rigtignok kunne misforstås. Det ligger i ordet tendenser, og da begynder ironien altså også. Dette kan nemlig forstås, som om jeg skulle opfatte Videnskabslæren som eksempel blot for en tendens, for et foreløbigt forsøg som Kants Kritik der reinen Vernunft, som jeg selv måske var bedre til at udføre og til sinds endelig at afslutte; eller som om jeg, for at sige det i kunstsproget - der for denne forestillingsart er den almindelige og også den mest passende - står på Fichtes skuldre, som denne på Reinholds skuldre, Reinhold på Kants skuldre, denne på Leibniz', og således i det uendelige til de oprindelige skuldre. -

Jeg vidste det udmærket, men jeg tænkte, at jeg alligevel én gang ville forsøge, om nogen mon ville tildigte mig en sådan slet. tanke. Ingen synes at have bemærket det. Hvorfor skal jeg frembyde misforståelser, når ingen vil begribe dem? Jeg lader herefter ironien fare, og erklærer ligeud, at ordet i fragmenternes dialekt betyder, at alt kun er tendens, tidsalderen er tendensernes tidsalder. Om jeg nu havde den mening, at alle disse tendenser skulle bringes til rigtighed og besluttes af mig selv - eller måske af min broder, eller af Tieck, eller af hvemsomhelst fra vores faktion, eller først af en af vore sønner, eller af et barnebarn, et oldebarn, en efterkommer i syvogtyvende led, eller først på den yderste dag, eller aldrig - dét overgives til visdommen hos læseren, hvem dette spørgsmål retteligen tilhører.

Goethe og Fichte forbliver den letteste og mest passende formel for al den anstød, som Athenæum har vakt, og for al uforståelse, 
som Athenæum har fremkaldt. Det bedste ville vel også her være at gøre det hele endnu værre; når forargelsen har nået den største højde, så rejser den og forsvinder, og så kan det at forstå samtidig tage sin begyndelse. Endnu er vi ikke kommet langt nok med at støde an: men det, der ikke er, kan blive. Ja, også hine navne må endnu nævnes mere end én gang igen, og så sent som idag har min broder gjort en sonet, som jeg ikke kan undlade at meddele læseren på grund af de fortryllende ordspil, som han (læseren) elsker næsten endnu mere end ironien:

Bewundert nur die feingeschnitzen Götzen, Und lasst als Meister, Führer, Freund uns Goethen:

Euch wird nach seines Geistes Morgenröten Apollos goldner Tag nicht mit ergötzen.

Der lockt kein frisches Grün aus dürren Klötzen, Man haut sie um, wo Feurung ist vonnöten.

Einst wird die Nachwelt all die Unpoeten

Korrekt versteinertsehn zu ganzen Flötzen.

Die Goethen nicht erkennen, sind nur Goten, Die Blöden blendet jede neue Blüte, Und, Tote selbst, begraben sie die Toten.

Uns sandte, Goethe, dich der Götter Güte, Befreundet mit der Welt durch solchen Boten,

Göttlich von Namen, Blick, Gestalt, Gemüte. ${ }^{6}$

En stor del af uforståeligheden i Athenæum ligger utvivlsomt i ironien, som mere eller mindre ytrer sig overalt deri. Jeg begynder også her med en tekst fra Lyceum-fragmenterne.

Den sokratiske ironi er den eneste fuldt ud vilkårlige og fuldt ud besindige forstillelse. Den er lige umulig at hykle og forråde. For den, som ikke har den, forbliver den selv efter den mest åbne tilståelse en gåde. Den skal ikke bedrage andre end dem, der holder den for bedrag, og enten glædes over det herlige skælmeri at have hele verden til bedste, eller bliver vrede, når de aner, at de vel også var indbefattet. I dén skal alt være ironi og alt alvor, alt troskyldigt åbent og alt dybt forstillet. Den udspringer af foreningen af videnskabelig ånd og sans for livskunst, af mødet mellem fuldendt naturfilosofi og fuldendt kunstfilosofi. Den 
rummer og vækker en følelse af den uløselige strid mellem det ubetingede og det betingede, det umulige og nødvendige i en fuldstændig meddelelse. Det er den frieste af alle licenser, for gennem den sætter man sig ud over sig selv; og dog også den mest lovmæssige, for den er ubetinget nødvendig. Det er et meget godt tegn, når de harmonisk platte slet ikke ved, hvordan de skal tage denne bestandige selvparodi, når de holder spøgen for alvor og alvoren for spøg. [Lessings ironi er instinkt; hos Hemsterhuys er den klassisk; Hülsens ironi udspringer af filosofiens filosofi, og kan i vidt mål overtræffe hine].7

Et andet af disse fragmenter melder sig i kraft af dets korthed:

Ironi er det paradoksales form. Paradoks er alt, som på een gang er godt og stort. 8

Må ikke enhver læser, som er vant til fragmenter i Athenæum, finde alt dette yderst let, ja, trivielt? Og dog forekom det dengang mange uforståeligt, nok fordi det endnu var nyt. Thi først sidenhen er ironien kommet på dagsordenen efter at denne mængde af store og små ironier af enhver art er skudt op i det nye århundredes morgendæmring, sådan at jeg snart vil kunne sige, som Boufflers siger om det menneskelige hjertes forskellige former:

Jeg har set hjerter i mangen en form

Stor, lille, tynd, tyk, ubetydelig, enorm. ${ }^{9}$

For at lette overblikket over ironiens samlede system, vil vi anføre nogle af de mest fremtrædende former. Den første og fornemste af dem alle er den grove ironi; den findes for det meste i tingenes virkelige natur og er en af dens mest almindeligt udbredte stoffer; den har først egentlig hjemsted i menneskehedens historie. Dernæst kommer den fine eller delikate ironi; så den ekstrafine; på denne måde arbejder Scaramouche,10 når han synes at drøfte venligt og ærligt med nogen, idet han kun afventer det øjeblik, hvor han på en god facon vil kunne aflevere et spark i bagen. Denne type kan vel også findes hos digterne, ligesom den redelige ironi, der på den reneste og oprindeligste måde er plantet i gamle haver, hvor vidunderligt liflige huler lokker 
naturens følsomme ven ind i deres kødelige skød, for så rigeligt at oversprøjte ham fra alle sider og således uddrive hans sarthed. Yderligere findes den dramatiske ironi, som når digteren har skrevet tre akter og så mod forventning bliver et andet menneske og derpå skal skrive de to sidste akter. Den dobbelte ironi optræder, når to ironiske linier løber parallelt uden at lade sig forstyrre af, at den ene henvender sig til parterret, den anden til logerne, hvorved små gnister kan flyve ud i kulisserne. Endelig er der ironiens ironi. I almindelighed er det vel den mest grundige ironiens ironi, at man end også bliver led og ked af den, når vi møder den overalt og igen og igen. Hvad vi her først og fremmest vil forstå under ironiens ironi, opstår på mere end een måde. Når man taler uden ironi om ironi, som det lige før var tilfældet; når man taler ironisk om en ironi uden at mærke, at man præcis på det tidspunkt befinder sig i en anden, meget mere påfaldende ironi; når man ikke kan komme ud af ironien igen, som det synes at være tilfældet i dette forsøg om uforståeligheden; når ironien bliver manér og således ligesom igen ironiserer digteren; når man har skænket sin ironi til en overflødig notesbog, uden på forhånd at have lavet et overslag over sit forråd, og nu modvilligt må være ironisk som en skuespiller, der har mavepine: når ironien bliver vild og slet ikke længere lader sig beherske.

Hvilke guder vil kunne redde os fra alle disse ironier? Den eneste mulighed ville være, om der fandtes en ironi, der havde den egenskab, at den kunne sluge og fortære alle hine store og små ironier, så der intet ville være at se af det, og jeg må tilstå, at jeg netop i den henseende fornemmer en mærkelig disposition $i$ min ironi. Men også dette ville kun kunne hjælpe på kort sigt. Jeg frygter, hvis jeg ellers forstår skæbnens vink rigtigt, at der snart vil opstå en ny generation af små ironier; thi sandelig, stjernebillederne tyder på noget fantastisk. Og forudsat at alt forblev i ro over længere tid, så ville det dog ikke være til at tro. Med ironi bør man absolut ikke spøge. Den kan virke utroligt længe efter. Nogle af den forrige tids mest overlagte kunstnere har jeg mistænkt for, endnu århundreder efter deres død, at udøve ironi over for deres mest troende tilbedere og tilhængere. Shakespeare har så uendeligt mange dybder, lumskheder og hensigter; skulle 
han ikke også kunne have haft hensigten at skjule kildne snarer for eftertidens åndrigeste kunstnere for at vildlede dem, så de, før de ved et ord af det, må tro, at de også er omtrent sådan som Shakespeare? Vist, han kunne også i den henseende være langt mere overlagt, end man formoder.

Jeg har allerede indirekte måttet komme med den tilståelse, at Athenæum er uforståelig, og fordi den er fremsat midt i et bål af ironi, kan jeg vanskeligt tilbagekalde den, thi derved ville jeg jo selv krænke ironien.

Men èr nu uforståeligheden noget helt igennem forkasteligt og slet? - Mig synes det, at familiers og nationers ve og vel beror på den, ja, hvis jeg ikke tager meget fejl, stater og systemer, menneskenes mest forfinede værker, ofte så forfinede, at man ikke tilstrækkeligt kan beundre skaberens visdom i dem. En utrolig lille portion er tilstrækkelig, når den blot forbliver bevaret ubrydeligt tro og ren, og ingen formastelig forstand vover at nærme sig den hellige grænse. Ja, det kosteligste, mennesket har, selve den indre tilfredshed, afhænger, som enhver ved, når alt kommer til alt, af et sådant punkt, der må forblive dunkelt, men ikke desto mindre bærer og holder det hele og ville miste denne kraft i samme øjeblik, som man ville opløse den i forstand. Sandelig siger jeg Eder, I ville blive bange, hvis hele verden, sådan som I kræver det, engang for alvor ville blive helt igennem forståelig. Og er den ikke selv, denne uendelige verden, dannet gennem forstanden ud af uforståeligheden eller kaos?

En anden trøst for den anerkendte uforståelighed i Athenæum ligger allerede i anerkendelsen selv, fordi netop denne belærte os om, at ondet vil være forbigående. Den nye tid forkynder sig som en rapfodet tid med bevingede sko; morgenrøden har trukket syvmilestøvlerne på. - Længe har det uvejrslyst ved poesiens horisont; i en mægtig sky var hele himlens uvejr sammentrængt; nu tordnede den mægtigt, nu syntes den at fortrække og lynede kun i det fjerne, for snart at vende så meget mere skrækkeligt tilbage: men snart vil der ikke være tale om eet enkelt uvejr, istedet vil hele himlen brænde i een flamme, og så vil alle jeres små lynafledere ikke hjælpe. Da begynder det nittende århundrede virkelig, og da vil hin lille gåde om uforståeligheden i Athenæum være 
løst. Hvilken katastrofe! Da vil der findes læsere, som kan læse. I det nittende århundrede vil alle med behag og fornøjelse kunne nyde fragmenterne i fordøjelsestimerne, og heller ikke til de hårdeste og mest ufordøjelige behøve nogen nøddeknækker. I det nittende århundrede vil ethvert menneske, enhver læser finde Lucinde ${ }^{11}$ uskyldig, Genoveva ${ }^{12}$ protestantisk og A.W. Schlegels didaktiske elegier ${ }^{13}$ næsten for lette og gennemsigtige. Det vil også her godtgøres, hvad jeg i profetisk ånd opstillede som maxime i de første fragmenter:

En klassisk skrift må aldrig kunne blive forstået helt. Men de, som er dannede, og danner sig, skal ville lære mere og mere af den. ${ }^{14}$

Den store skilsmisse mellem forstand og uforstand bliver mere og mere almindelig, heftigere og klarere. Endnu megen gemt uforståelighed må bryde ud. Men også forstanden vil vise sin almagt; den, der adler sindet til karakter og talentet til geni, den, der lutrer følelsen og anskuelsen til kunst; den vil selv blive forstået, og man vil endelig måtteindse og indrømme, at enhver kan opnå det højeste, og at menneskeheden indtil nu hverken har været ondskabsfuld eller dum, men kun ubehændig og ny. Jeg holder inde her for ikke at krænke den højeste guddoms ærbødighed før tiden. Men de store grundsætninger, sindelagene, som det kommer an på der, lader sig meddele uden krænkelse; og jeg har forsøgt at udtrykke det væsentlige deraf, idet jeg tilsluttede mig et vers af digteren, som er ligeså dybsindigt som det er elskværdigt, i den form af digtningen, som spanierne kalder glosse; ${ }^{15}$ og der bliver nu ikke andet tilbage at ønske, end at en af vore fortræffelige komponister finder min glosse værdig til musikalsk ledsagelse. Der findes ikke noget smukkere på jorden, end når poesi og musik i huld samdrægtighed virker til menneskehedens forædling.

Eines schickt sich nicht für alle,

Sehe jeder wie er's treibe,

Sehe jeder wo er bleibe,

Und wer steht dass er nicht falle. 
Dieser weiss sich seher bescheiden Jener bläst die Baken voll;

Dieser ist im Ernste toll, Jener muss ihn noch beneiden. Alle Narrheit kann ich leiden, $\mathrm{Ob}$ sie genialisch knalle, Oder blumenlieblich walle;

Denn ich werd es nie vergessen,

Was des Meisters ermessen:

Eines schickt sich nicht für alle.

Um das Feuer zu ernähren,

Sind viel zarte Geister nötig,

Die zu allem Dienst erbötig,

Um die Heiden zu bekehren.

Mag der Lärm sich nun vermehren,

Suche jeder wen er reibe,

Wisse jeder was er schreibe,

Und wenn schrecklich alle Dummen

Aus den dunkeln Löchern brummen,

Sehe jeder wie er's treibe.

Ein'ge haben wir entzündet,

Die nun schon alleine flammen;

Doch die Menge hält zusammen,

Viel Gesindel tru verbündet.

Wer den Unverstand ergründet, Hält sich alle gern vom Leibe, Die geboren sind vom Weibe. Ist der Bienenschwarm erregt, Den das neu'ste Wort bewegt Sehe jeder wo er bleibe.

Mögen sie geläufig schwatzen, Was sie dennoch nie begreifen. Manche müssen irre schweifen, Viele Künstler werden platzen. Jeden Sommer fliegen Spatzen, Freuen sich am eignen Schalle: Reitzte dies dir je die Galle? Lass sie alle selig spielen, Sorge du nur gut zu zielen, Und wer steht dass er nicht falle. 


\section{Tale om mytologien (1800)16}

Med den alvor, hvormed I ærer kunsten, mine venner, vil jeg opfordre jer til at spørge jer selv: Skal begejstringens kraft også i poesien uafladeligt stykke sig ud i alt for mange stumper, og når den har kæmpet sig træt mod det modbydelige element, så endelig forstumme i ensomhed? Skal det højeste hellige altid forblive navnløst og formløst, i mørket overladt tilfældet? Er kærligheden virkelig uovervindelig, og findes der mon en kunst, som fortjente navnet, hvis den ikke har magten til at lænke kærlighedens ånd gennem dens trylleord, så ånden følger kunstens bud og efter dens nødvendige vilkår må besjæle de skønne dannelser?

I, af alle, må vide, hvad jeg mener. I har selv digtet, og I må i jeres digten ofte have følt, at I $\mathrm{i}$ jeres virke fattedes et fast ståsted, en moderlig grund, en himmel, en levende luft.

Den moderne digter skal arbejde fra det indre og udad. Mange har gjort det herligt, men indtil nu kun hver især, alene; hvert værk som en ny skabelse, fra begyndelsen, ud af intet.

Jeg går straks til målet. Vor poesi, påstår jeg, mangler et midtpunkt, som mytologien var de gamles, og det væsentlige, som gør at den moderne digtekunst ligger bag efter den antikke, lader sig sammenfatte i ordene: $V i$ har ingen mytologi. Men jeg tilføjer, at vi er tæt på at få en, eller snarere: det er på tide, at vi alvorligt medvirker til at frembringe en.

Thi den vil komme til os ad en vej helt modsatrettet den gamle, tidligere, overalt den ungdommelige fantasis første blomstring, umiddelbart tilsluttende og dannende sig til det nærmeste, mest levende i sansernes verden. Den ny mytologi må tværtimod dannes ud fra åndens dybeste dybde; den må være det kunstigste af alle kunstværker, thi den skal omfatte alle andre, et nyt leje og kar for poesiens gamle, evige urkilde og det uendelige digt, som tilhyller alle andre digtes kim.

I vil måske trække på smilebåndene af dette mystiske digt og over den uorden, der måtte opstå af trængslen og fylden af digtninger. Men den højeste skønhed, ja, den højeste orden, er 
dog kun dette 'kaos', en sådan, nemlig, som blot venter på kærlighedens berøring for at udfolde sig til en harmonisk verden, sådan som også den gamle mytologi og poesi var det. Thi mytologi og poesi, begge er ét og uadskilleligt. Alle oldtidens digte tilslutter sig hinanden, et for et, indtil helheden danner sig ud af stadig større masser; alting griber ind i hinanden, og overalt er en og samme ånd, blot udtrykt anderledes. Og således er det i sandhed ikke et tomt billede at sige: den gamle poesi er ét eneste, udeleligt, fuldendt digt. Hvorfor skulle det, der allerede har været, ikke igen kunne blive til påny? På en anden måde, forstås. Og hvorfor ikke på en smukkere, større? -

Jeg beder jer blot om ikke at give plads for vantroen på muligheden af en ny mytologi. Tvivl fra alle sider og i alle retninger skal være mig velkommen, derved kan undersøgelsen blive desto friere og rigere. Og lån nu mine formodninger et opmærksomt øre! Mere end formodninger kan jeg i sagens natur ikke ville give. Men jeg håber, at disse formodninger bliver til sandheder gennem jer selv. Thi, hvis I vil gøre dem til dette, er der tale om forslag til forsøg.

Kan en ny mytologi kun komme frem fra åndens inderste dybde, som af sig selv, så finder vi et meget betydende vink i og en mærkværdig bekræftelse på det, vi søger, i tidsalderens største fænomen, i idealismen! Denne er netop på samme måde opstået ud af intet, og der er nu også i åndens verden konstitueret et fast punkt, hvorudfra menneskets kraft i stigende udvikling kan udbrede sig til alle sider, værende sikker på aldrig at miste sig selv eller sin tilbagevenden. Alle videnskaber og alle kunstarter vil den store revolution omfatte. I ser den allerede virke $i$ fysikken, i hvilken idealismen egentlig allerede tidligere brød ud, inden den endnu var berørt af filosofiens tryllestav. Og dette vidunderlige, store faktum kan samtidig være et vink for jer om tidsalderens hemmelige sammenhæng og indre enhed. Idealismen, i praktisk henseende ikke andet end denne revolutions ånd, samme store maksimer, som vi af egen kraft og frihed skal udøve og udbrede; i teoretisk henseende, så stor den også måtte vise sig her, dog kun en del, en kvist, en ytringsmåde af alle fænomeners fænomener, så menneskeheden af alle kræfter brydes for at finde 
dens centrum. Som sagerne står, må den gå under eller forynges. Hvad er mest sandsynligt, og hvad vil man ikke håbe om en sådan foryngelsens tidsalder? - Den grå oldtid vil igen blive levende, og den fjerneste fremtids dannelse melde sig i varsler. Det er dog foreløbig ikke dette, det kommer an på: thi jeg vil helst ikke springe noget over, men skridt for skridt føre jer ind til de allerhelligste mysteriers vished. Ligesom det er åndens væsen at bestemme sig selv og at gå ud af sig selv og vende tilbage til sig selv i bestandig vekslen; ligesom enhver tankeikke er andet end resultatet af en sådan aktivitet: så er den samme proces synlig $i$ det hele og store i enhver form af idealismen, som jo selv kun er anerkendelsen af denne egenlov, og det nye, gennem anerkendelsen, fordoblede liv, som på det herligste åbenbarer sammes hemmelige kraft gennem ny opfindelses uindskrænkede fylde, gennem den almene meddelelighed og gennem den levende virkning. Naturligt nok antager fænomenet $i$ hvert individ en bestemt skikkelse, hvor succesen da ofte ikke vil svare til vore forventninger. Men hvad nødvendige love lader forvente af helhedens gang, deri vil vi ikke blive skuffede i vore forventninger. Idealismen i enhver form må på en eller anden måde gå ud af sig selv for at kunne vende tilbage sig selv, og forblive det, den er. Derfor skal og vil en ligeså grænseløs realisme hæve sig af dens skød; og idealismen, altså ikke blot i dens oprindelsesmåde et eksempel for den nye mytologi, derimod selv, indirekte, kilde til samme. Sporene af en lignende tendens kan I allerede nu sande næsten overalt; især i fysikken, der tilsyneladende ikke mangler andet end en mytologisk anskuelse af naturen.

Også jeg har længe båret en sådan realismes ideal i mig, og når det hidtil ikke er blevet til nogen meddelelse, så er det kun fordi, jeg endnu søger organet dertil. Dog ved jeg, at jeg kun kan finde det i poesien, thi i filosofiens skikkelse, eller i et system overhovedet, vil realismen aldrig mere kunne optræde. Og selv ifølge en almindelig tradition må det forventes, at denne nye realisme, fordi den dog er af idealisk oprindelse, og samtidig må svæve på idealisk bund og grund, vil vise sig som poesi, der jo skal bero på harmonien mellem det ideelle og det reellé. 
Spinoza synes mig at have en skæbne som ligner fablens gode, gamle Saturn. ${ }^{17}$ De nye guder har styrtet den herlige fra videnskabens høje trone. I fantasiens hellige mørke er han veget tilbage, dér lever og huserer han nu med de andre titaner i ærværdig landflygtighed. Hold ham fast her! Lad hans erindring om det gamle herredømme, i musernes sang, smelte sammen til en sagte længsel. Lad ham afklæde sig systemets krigeriske prydelse og da dele bolig med Homer og Dante i den nye poesis tempel og slutte sig til enhver gudebegejstret digters larer og husvenner. Jeg forstår virkelig ikke, hvordan man kan være digter uden at højagte Spinoza, uden at elske ham og helt være hans. Ved opfindelsen af det enkelte er jeres fantasi rig nok; at anspore den, at ægge den til handling og give den næring, dertil er intet bedre egnet end andre kunstneres digtning. Hos Spinoza finder I imidlertid al fantasis begyndelse og ende, den almene bund og grund hvorpå jeres enkelte hviler; og netop denne afsondring fra fantasiens oprindelige, evige, fra alt det enkelte og særlige, må være jer særdeles velkommen. Grib lejligheden og sku derhen! I vil blive forundt et blik ind i poesiens inderste værksteder. Spinozas følelse er af samme art som hans fantasi. Ikke modtagelig for dette og hint, ikke lidenskab, som stiger og synker igen; men en klar duft svæver over det hele, overalt vinder den evige længsel anklang fra dybder i det enkle værk, der i stille storhed ånder den oprindelige kærligheds ånd.

Og er dette milde genskin af det guddommelige i mennesket ikke al poesis egentlige sjæl og tændende gnist? - Den blotte fremstilling af mennesker, lidenskaber og handlinger kan så san'delig ikke gøre det, lige så lidt som de kunstige former; om I så også rafler og vælter det gamle gods sammen millioner af gange. Det er kun den synlige, ydre krop - og når sjælen er slukt, blot poesiens døde lig. Om hin entusiasmes gnist imidlertid bryder ud i værket, så åbenbarer en ny skikkelse sig for os, levende og med en smuk glorie af lys og kærlighed.

Og hvad er enhver smuk mytologi andet end et hieroglyfisk udtryk for den omgivende natur i denne forklarelse af fantasi og kærlighed? 
Et stort fortrin har mytologien. Det, der ellers undflyr bevidstheden, er her alligevel muligt at skue sanseligt åndeligt, fastholdt, som sjælen i den omgivende krop, gennem hvilken den skinner i vort øje og taler til vort øre.

Det er den egentlige grund til, at vi, stillet over for det højeste, ikke helt forlader os på sindet. Den, der dér har sit på det tørre, vil ganske vist ikke blive våd; og det er en velkendt sandhed, som jeg skulle være den sidste til at bestride. Men vi bør overalt tilslutte os det dannede og også det højeste gennem berøring af det ensartede, lignende, eller med samme værdighed udvikle, antænde, nære, med ét ord, danne det fjendtlige. Er det højeste imidlertid ikke i stand til forsætlig dannelse; så lad os blot straks opgive ethvert krav på enhver fri idékunst, som ellers ville være et tomt navn.

Mytologien er et sådant naturens kunstværk. I dets væv er det højeste virkelig dannet; alt er forbindelse og forvandling, tildannet og omdannet, og denne tildannen og omdannen er netop dens ejendommelige fremgangsmåde, dens indre liv, dens metode, om jeg så må sige.

Deri finder jeg altså en stor lighed med den romantiske poesis store vits, som ikke viser sig i enkelte indfald, derimod i helhedens konstruktion, og som vor ven så ofte har udviklet i Cervantes' og Shakespeares værker. Ja, denne kunstigt ordnede forvirring, denne henrivende symmetri af modsigelser, denne vidunderlige, evige vekslen mellem entusiasme og ironi, som lever i selv de mindste lemmer af helheden, synes mig allerede selv at være en indirekte mytologi. Organisationen er den samme, og vist er arabesken fantasiens ældste og oprindeligste form. Hverken denne vits eller en mytologi kan findes uden et første oprindeligt og uefterligneligt, som simpelthen er uopløseligt, som efter alle omdannelser stadig lader den gamle natur skinne igennem, hvor det naive dybsind lader skæret fra det forkerte og det forrykte, eller det enfoldige og dumme skinne igennem. Thi dét er al poesis begyndelse: at ophæve gangen og lovene for den fornuftigt tænkende fornuft, og igen hensætte os i fantasiens skønne forvirring, igen hensætte os i den menneskelige naturs 
oprindelige kaos, for hvilket jeg ind til nu ikke kender noget bedresymbol end de gamle guders farverige vimmel.

Hvorfor vil I ikke hæve jer op til at give nyt liv til den store oldtids herlige skikkelser? - Forsøg blot en gang at betragte den gamle mytologi fuld af Spinoza og af de anskuelser, den nutidige fysik må fremkalde, og se hvorledes alt vil fremstå i ny glans, med nyt liv.

Men også de andre mytologier må igen vækkes alt efter deres dybsind, deres skønhed og deres dannelse, for at fremskynde den ny mytologis fremkomst. Var Orientens skatte blot lige så tilgængelige for os som oldtidens! Hvilken ny kilde af poesi kunne ikke flyde fra Indien, hvis nogle tyske kunstnere, med sindets universalitet og dybde, med oversættelsens geni, som er dem egen, havde de muligheder, som en nation, der bliver stadig mere afstumpet og brutal, kun ringe forstår at gøre brug af. I Orienten skal vi søge det højeste romantiske, og når vi først kan øse af kilden, så vil synet af sydlig ild, der nu forekommer os så dragende i den spanske poesi, igen kun synes vesterlandsk og sparsom.

I det hele taget skal man kunne trænge frem til målet ad mere end én vej. Enhver gå sin egen vej, i glad fortrøstning, på den mest individuelle måde, thi intetsteds gælder individualitetens rettigheder mere end her, hvor der er tale om det højeste - hvis den kun er det, som ordet betegner, udelelig enhed, indre, levende sammenhæng; et standpunkt, ud fra hvilket jeg ikke ville have betænkeligheder ved at sige, at menneskets egentlige værdi, ja dets dyd, var dets originalitet. -

Og når jeg lægger så stor vægt på Spinoza, så sker det ikke på baggrund af en subjektiv forkærlighed (hvis genstande jeg tværtimod udtrykkeligt har holdt langt borte), eller for at ophøje ham til mester for et nyt eneherredømme; men fordi jeg med dette eksempel mest opsigtsvækkende og indlysende kunne vise mine tanker om mystikkens værdi og værdighed samt dens forhold til poesien. Jeg valgte ham på grund af hans objektivitet, i den henseende repræsentant for alle øvrige. Jeg tænker således over det. Ligesom Videnskabslæren ifølge de personers anskuelse, som ikke har bemærket idealismens uendelighed og uforgænge- 
lige fylde, $i$ det mindste forbliver en fuldendt form, et alment skema for al videnskab: således er også Spinoza på lignende måde det almene grundlag for enhver individuel form af mysticisme; og dette, tror jeg, vil også de, der hverken forstår særlig meget af mysticismen eller Spinoza, beredvilligt anerkende.

Jeg kan ikke slutte, uden nok en gang at opfordre til at studere fysikken, ud fra hvis dynamiske paradoxier naturens helligste åbenbaringer nu bryder ud fra alle sider.

Og så lad os da, ved lys og liv!, ikke længere tøve, men, hver efter sin overbevisning, fremskynde den store udvikling, som vi er kaldet til. Vær tidsalderens storhed værdig, og skæl vil falde fra jeres øjne; der vil blive klarhed for jer. Al tænken er en divineren, men mennesket er først i færd med at blive sig sin divinatoriske kraft bevidst. Hvilke umålelige udvidelser vil det endnu erfare; og netop nu. Mig forekommer det, at den, der kunne forstå tidsalderen, det vil sige den almene, store foryngelsesproces, og den evige revolutions evige principper, den måtte det kunne lykkes at gribe menneskehedens poler og de første menneskers gøren, og ligeledes vide at erkende karakteren af den gyldne tid, som skal komme. Så ville snakken ophøre, og mennesket ville blive sig selv var og forstå jorden og solen.

Det er dette, jeg mener med den nye mytologi.

[...]

Fra hefterne om filosofi (1794-1818)

Filosofiske fragmenter. Første epoke. I

[11] Det er egentlig af mystikerne, vi nu må lære filosofien.

[12] Spinoza den bedste af os kendte mystikere før Fichte.

[13] Mystikeren er friere end skeptikeren og empirikeren; han frembringer sin modsigelse; hine lader sig give samme - det er modsigelsen i tredje potens - det er en positiv modsigelse. - Empirikeren bygger på tomheden, på negative modsigelser. My- 
sticismen også den mest nøgterne og mest solide af al rasen, den mægtigste.

[15] Alle tre har deres eget sprog og dog protesterer alle tre, skeptiker, empiriker, mystiker mod terminologien. Empirikeren af mangel på evne, og fordi han anser det absolutte for at være en tom abstraktion. Skeptikeren af protestantisme og bestemmelsesløshed, og den ægte mystiker af had til bogstavet. Mystikeren har det vel som på anden måde kun at gøre med anskuelse, hader ikke kun bogstavet, men også begrebet. Bogstavets apologi, der som meddelelsens eneste ægte vehikel er meget ærværdig.

[21] Hemsterhuys er en eklektisk mystiker, men den eneste ægte sokratiker i sin tidsalder.

[24] Kristus var en ren mystiker.

[33] HVAD kan jeg vide? er kun halvdelen af problemet; den anden halvdel er: HVORDAN kan jeg vide?

[39] Mystikere er mestre i det absoluttes urvidenskab. - At beskæftigelsen med det absolutte helt absorberer dem, og at den gør dem aldeles uduelige og ubehændige i verden, er yderst begribeligt. - Det er derfor meget ukritisk blot at ville forklare deres tænkemåde patologisk. En og anden skulle prøve at måle sin lo-giske kunst og kraft med Spinoza og Fichte! - Også i andre, ikke så gode mystikere, finder man den højeste strenghed og alle kunstens regler. De er altså ikke ubehændige af manglende evne, men af evne.

[40] Mystikken tragter så absolut efter absolut enhed.

[42] Identitet mellem subjektet og objektet, en naturlig tanke for mystikeren.

\section{Filosofiske fragmenter. Første epoke. II}

[378] Fichte er kantisk, som Platon er sokratisk.

[379] Moden det højeste praktiske groteske.

[380] Revolutionen tidsalderens tragiske arabesk.

[431] Skulle Kants bogstav ikke være mere værd end hans ånd? [601] I en filosofiens kritik må filosofien nødvendigvis betragtes som kunst. 
[815] Jeg er en fragmentarisk systematiker og romantisk filosof og systematisk kritiker.

[822] Et ordentligt dannet menneske må samtidig være voksen og barn.

[832] Et ordentligt system af fragmenter måtte SAMTIDIG være subjektiv og objektiv.

[857] Min filosofi er et system af fragmenter og en progression af projekter.

[945] Den absolutte sætten og det absoluttes sætten er mytologiens karakter.

[1043] Hvert menneske er kun et stykke af sig selv. [1053] Man kan som Sokrates improvisere filosofi, men kun sokratisk.

[1056] Uden sans for det groteske findes der ingen universalitet. Det groteske er universalspil.

[1060] I politiet er magterne åbenbart ikke delte; de er mere absolutte. I politiet må Frankrig vel være kommet frem til ironien.

Filosofiske fragmenter. Første epoke. III

[16] Den højeste kritik står i den tætteste forbindelse med den logisk praktiske musik, og med den logisk praktiske Gymnastik. Kritik er abstraktionskunsten. Vits kombinationskunsten. Historisk musik er den mest dannede mystik.

[130] Læsen og skriven kun forskellige i graden.

[140] I treheden af satire, elegi, idyl er ikke idyllen, men elegien det højeste.

[173] Krampe er gigt i handling, og gigt er krampe i ro. Den egentlige vellystning er den simple egoist; denne ender også i åndelig henseende med podagra.

[178] Matematikken er slet og ret videnskaben, ikke den man begynder med, men den man ender med.

[180] Matematikken selv kan måske slet ikke meddeles i sproget, derimod kun matematikkens filosofi.

[204] Fragmentets genstand er et filosofisk individ, en levende tanke, conceptus. 
[224] En karakteristik er et kritisk eksperiment, et fragment et kritisk frenomen, et åndeligt.

[232] Poesien er en uendelig retorik og en logisk åndelig musik. [239] Vitsen er helt kritisk. Ethvert bonmot samtidig karakteristik og fragment.

[250] Har lysets bevægelse ikke noget absolut over sig, vandet noget transcendentalt?

\section{Til poesi og litteratur (1812)}

[7] Den eneste egentlig nye form, som den tyske litteratur i den sidste tid har vundet, er kritikken. Alt andet er endnu ganske formløst.

[120] Vore digtere er enten FORMSØGENDE, som Klopstock, Schiller, Goethe; eller FORMLØSE, som Wieland, Bürger, Tieck, Friedrich Richter. Formen (den sande, nemlig, kommer kun fra den højere region).

[127] Der findes to slags følelser; den ene kan sammenlignes med vandet, og den hersker i musikken. Den anden ligner ilden; det er begejstringens flammer, der hersker i retorikken.

XXII Til poesi og litteratur. (1823)

[3] De fire elementærkræfter, eller kunstarter og videnskaber i talen, er:

Kritik

Poesi Filosofi

Retorik

Det er egentlig kun former, til hvilke hine andre materielle videnskaber leverer stoffet. 
Til historie og politik. (1828. I. Juli)

[5] Blandt de forhåndenværende sprog er måske det indiske (som det ældste i sin familie), det hebraiske, det ægyptiske og det kinesiske (som der hvor de ældste skriftmindesmærker forefindes) at betragte som de fire strømme, som ligger tættest på det skjulte ursprogs tabte kilde.

Oversættelse og noter ved Ole Egeberg

\section{Noter}

1 Ideen er overskriften til en fragmentrække i Athenäum (1800). Samtlige noter er oversætterens anmærkninger.

2 Trykt i Athenäum.

3 Christian Garve (1742-98): tysk filosof. Oversatte engelske og klassiske moralforfattere. Leverede i Abhandlung über die verschiedenen Prinzipien der Sittenlehre von Aristoteles bis auf unsere Zeit (1804) en skarp kritik af Kant. Blandt hans skrifter kan anføres Versuche über verschiedene Gegenstände aus der Moral, Litteratur und dem gesellschaftlichen Leben I-V. (1792-1802)

4 Christoph Girtanner: læge i Göttingen, som foruden alkymistiske eksperimenter, gjorde kemiske og fysiske undersøgelser.

5 Athenäumsfragment nr. 216 (1798).

6 Dette digt er noget nær et skoleeksempel på det, Benjamin kalder "unübersetzbarkeit". Ordspillene, der svæver henover og imellem det platte og subtile, er uoversættelige. En fortolkende gendigtning ville blive mere komisk end relevant. Det samme gælder det afsluttende poem.

7 Lyceumsfragment nr. 108 (1797). Slutbemærkningerne i skarp parentes er udeladt både her og i Charakteristiken und Kritiken (1801). I Lyceum der schönen Kunste står de som monumenter over de tre kardinalbegreber, som Schlegel sætter i forbindelse med ironien: forstillelse, selvparodi og ironi. Schlegel understreger hermed, at fragmentet ikke kun handler om den sokratiske ironi. Der er snarere tale om, at han koncipe- 
rer konturerne af sit eget ironibegrebi en sokratisk-ironisk form. Og så melder spørgsmålet sig umiddelbart:hvorfor udeladelsen her og i 1801 ? 8 Lyceumsfragment 48 .

9 "J'ai vu des coeurs de toutes formes,/Grands, petits, minces, gros, mediocres, énormes". Stanislas Chevalier de Boufflers (1738-1815) skrev samfunds- og lejlighedsdigte i rokokostil.

10 Scaramouche: komisk figur, bl.a. hos Molière.

11 Lucinde, der udkom i år 1800, udgjorde angiveligt den ene del af et romanprojekt, hvis to dele skulle omhandle det mandliges læreår (Lucinde) og det kvindeliges læreår. Anden del blev aldrig skrevet færdig, men eksisterer kun som notater og udkast.

12 Genoveva: Paris' værnehelgen (ca. 420-502). Legenden fortæller bl.a., at hun reddede Paris ved Attilas indfald i Gallien. I 1843 bearbejdet til en tragedie i fem akter af Friedrich Hebbel.

13 A.W. Schlegel forsøgte med sine læredigte at forbinde poesi og filosofi.

14 Lyceumsfragment nr. 20.

15 Glosse: spansk lyrisk digtform (14.-16. årh). Benytter sig af fire decimer, som gennemspiller et motto (på fire vers). At Schlegel vælger netop denne form er næppe tilfældigt. Glosse har nemlig yderligere tre betydninger, som for opsatsen ikke er uvæsentlige: 1) polemisk aviskommentar til aktuelle begivenheder; 2) i talesproget en lumsk og spottende rand- eller sidebemærkning 3) oprindelig (fra gr. glossa: tunge, sprog) et uforståeligt og forklaringskrævende udtryk, og senere forklaring eller oversættelse af det uforståelige.

16 Trykt i Athenäum. Denne tale er en del af en større tekst med titlen: Samtale om poesien (Gespräch über die Poesie). Teksten indeholder forskellige genrer (brevformen, diskussionen, monologen som tale og som indre monolog samt en opsats, der tillige fremstår som recension). I nærværende oversættelse af Tale om poesien er en diskussion, mellem selskabets deltagere efter talen, udeladt.

Ligesom i fragmenterne er det dialogiske og polyfone fremtrædende. Ydermere betones det arrangerede og iscenesatte, samtalen som forestilling og forstillelse. Man kunne måske også sige kritik som kunst, filosofi som poesi.

17 Saturn: romersk gud, konge af Latium. Fra det 3. årh. f.v.t. sidestilles han med Kronos. Igen: Friedrich Schlegels eksempelvalg er nok ikke tilfældigt - saturnalier, tid og uendelighed. 


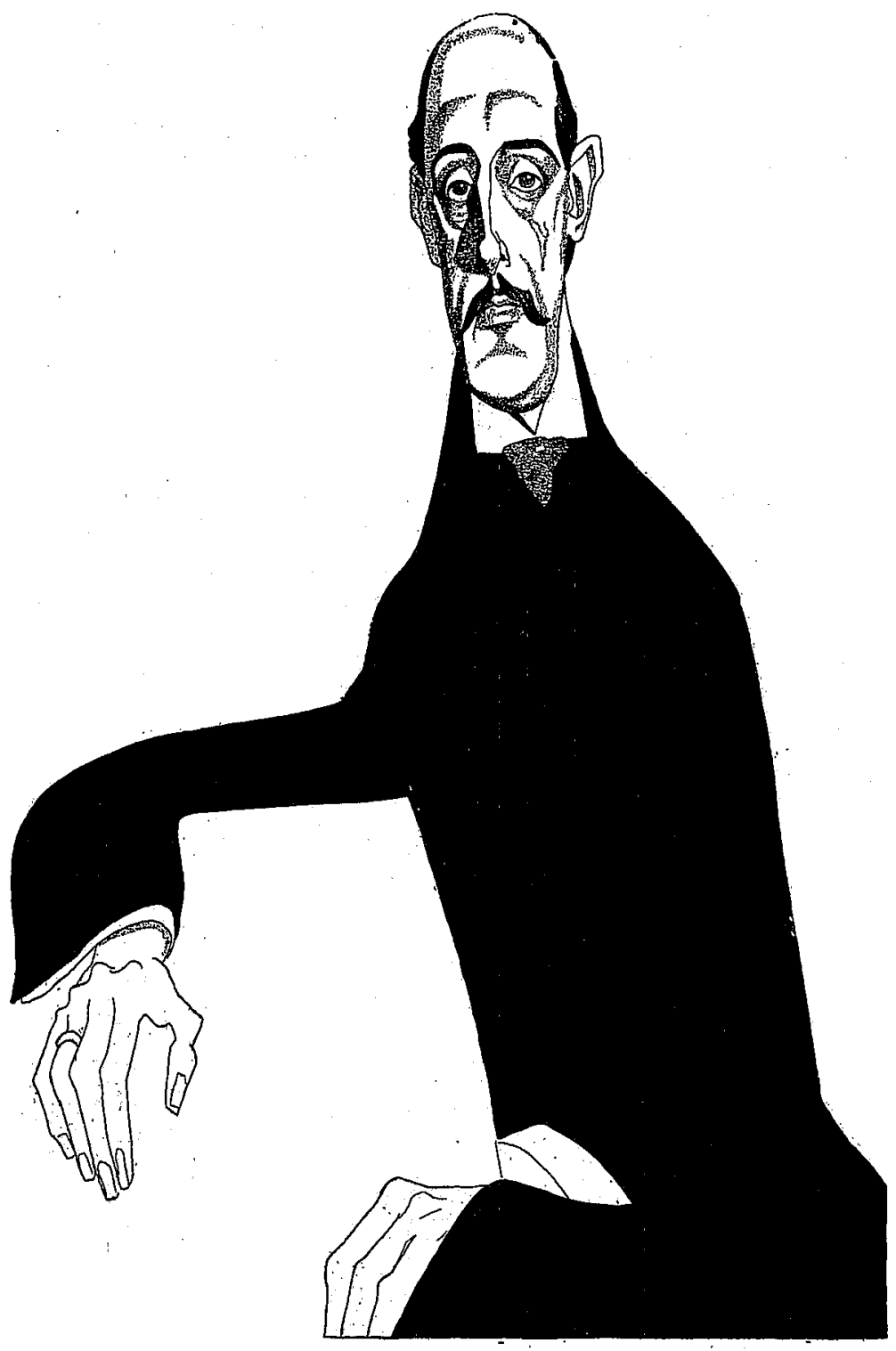

